\title{
Sistem Pakar Menentukan Maksimal Kalori Harian Berbasis Mobile
}

\author{
Teddy Santya ${ }^{1}$, Cosmas Eko Suharyanto ${ }^{2}$, Pastima Simanjuntak ${ }^{3}$, Alex Alfandianto ${ }^{4}$ \\ ${ }^{1,2,3}$ Program Studi Teknik Informatika Universitas Putera Batam, Jl. LetJend. Soeprapto, Tembesi, Kota Batam, Kepulauan Riau, Indonesia \\ ${ }^{4}$ Program Studi Teknik Industri Universitas Teknologi Yogyakarta, Mlati, Kabupaten Sleman, Daerah Istimewa Yogyakarta, Indonesia
}

\section{INFORMASI ARTIKEL}

Sejarah Artikel:

Diterima Redaksi: 11 September 2019

Revisi Akhir: 11 Oktober 2019

Diterbitkan Online: 14 Oktober 2019

\section{KATA KUNCI}

Aplikasi Mobile,

BMI,

Diet,

Kalori,

Sistem pakar

KORESPONDENSI

Telepon: +6285668174530

E-mail: cosmas@puterabatam.ac.id

\section{A B $\mathbf{S}$ T $\mathbf{R}$ A $\mathbf{C}$ T}

The study was conducted because of many concerning event happened in purpose of losing weight in improper methods. By the flow of time with technologies developed in this century, Smartphone became one of necessity because of the feature by many applications which helps a lot in our everyday life of humanity. The Researcher conducted this research of mobile-based application expert system which helps people properly losing their weight, this expert system is a supporting utility for taking care of dietary habit based on the amount of calorie limit calculated by this system, and recommends suitable and healthy food for users. This system is built with React Native framework. The calculation in this system is based on information of weight, height, and age provided by users, and all prediction will not be done without the provided information and every calculation is handled by web-based server-side processing which is developed using Laravel Framework. Inference method used by the researcher is Forward Chaining. This expert system will validate user's requirement to start working on losing weight by using Forward Chaining Inference method. Every successfully registered user will be able to view their calculated information by this system which is maximum calorie value, and list of healthy and recommended foods information provided by the expert herself. From the test results, the Expert System can solve the problem of giving a way to run a proper diet program by adjusting the diet with the calories needed.

\section{PENDAHULUAN}

Jenis diet sangat dipengaruhi oleh latar belakang asal individu atau keyakinan yang dianut masyarakat tertentu. Walaupun manusia pada dasarnya adalah omnivore, suatu kelompok masyarakat biasanya memiliki preferensi atau pantangan terhadap beberapa jenis makanan. Oleh karena itulah kata "diet" tidak bias digeneralisasi sebagai "tidak" makan. Kebutuhan akan asupan nutrisi merupakan salah satu kebutuhan mendasar bagi manusia untuk bertahan hidup. Nutrisi tersebut juga harus memiliki persyaratan kelengkapan gizi untuk pemenuhan secara sempurna bagi seseorang dalam melengkapi kebutuhan nutrisi.

Seseorang dapat dengan mudah mengurangi berat badannnya tanpa perlu mengonsumsi obat-obatan pembakar lemak dan semacamnya hanya dengan melakukan diet yang sehat, yaitu dengan meningkatkan aktivitas serta mengurangi asupan makanan/minuman (kalori) ke dalam tubuhnya. Inilah pengertian kunci yang harus kita pahami sebelum melakukan program diet sehat (jika mengalami kelebihan berat badan dan melakukan program diet sehat penurunan berat badan).

Kalori merupakan salah satu nilai yang penting untuk menjaga keseimbangan berat badan. Untuk itu tujuan penelitian ini adalah untuk mengetahui cara menurunkan berat badan manusia dengan baik dan benar, mengetahui perhitungan kebutuhan kalori untuk menurunkan berat badan, dengan maksud dapat membantu masyarakat yang mengalami kesusahan dalam menurunkan berat badan, selain itu juga untuk mengetahui faktor-faktor yang mempengaruhi berat badan serta mengurangi jumlah penyakit yang timbul karena diet.

Kementerian Kesehatan Republik Indonesia, melalui Laporan Survei Riskesdas tahun 2018, mengungkapkan fakta bahwa $21.8 \%$ penduduk Indonesia mengalami obesitas, meningkat dari survei tahun 2013 yang hanya $14.8 \%$ [1].

Masalah-masalah inilah yang mendorong untuk membuat penelitian ini diselesaikan dengan menciptakan 
sebuah aplikasi sistem pakar yang dapat menjadi panduan untuk menjalankan program diet demi menurunkan berat badan.

\section{TINJAUAN PUSTAKA}

\subsection{Kalori}

Kalori adalah satuan energi, dan kalori makanan menggambarkan jumlah energi potensial yang terkandung dalam makanan tertentu. Makanan yang dikonsumsi oleh manusia dapat mengandung nutrisi kalori (pemberi energi) dan non-kalori (bukan pemberi energi). Makronutrien, seperti karbohidrat, lemak, protein dan alkohol adalah nutrisi kalori dan, ketika dikonsumsi, menghasilkan akumulasi kalori dalam tubuh [2].

Makanan berkalori tinggi adalah makanan yang mengandung sejumlah besar nutrisi makro atau kombinasi nutrisi ini dalam bentuk cair, padat, atau semi padat. Nutrisi kalori memasok tubuh dengan energi yang dibutuhkan untuk aktivitas metabolisme, fisik, dan mentalnya sehari-hari. Jika tubuh telah memenuhi kebutuhannya akan kalori yang dibutuhkan untuk aktivitas sehari-hari, sisanya atau kelebihan kalori disimpan sebagai lemak dalam jaringan adiposa. Perlu dicatat bahwa semua kalori makanan, apakah itu berasal dari protein, karbohidrat, lemak atau alkohol dapat dikonversi menjadi lemak. Akumulasi lemak secara bertahap dalam tubuh menyebabkan peningkatan berat badan secara bertahap dan seiring waktu, jika kalori lemak tidak dibakar melalui metabolisme atau hilang melalui aktivitas fisik atau olahraga teratur, peningkatan akumulasi lemak berkontribusi pada penambahan berat badan dan kelebihan berat badan [3].

Pada dasarnya kelebihan berat hasil dari ketidakseimbangan energi yang disebabkan ketika ada kelebihan asupan energi (yaitu Makan lebih banyak kalori daripada yang sebenarnya dibutuhkan), atau penurunan pengeluaran energi (tidak membakar cukup kalori yang dikonsumsi melalui aktivitas fisik, olahraga \& metabolisme) atau kombinasi kelebihan asupan energi dan penurunan pengeluaran energi. Situasi ini di mana asupan energi lebih dari output energi mengarah pada keseimbangan energi positif dan penyimpanan energi. Penyimpanan energi berlebih bermanifestasi sebagai akumulasi lemak, penambahan berat badan, kelebihan berat badan dan obesitas. Perlu juga dicatat bahwa obesitas terkadang disebabkan oleh faktor-faktor yang tidak berhubungan dengan diet dan aktivitas. Beberapa faktor [4] yang dipublikasikan dalam literatur berkontribusi atau menyebabkan epidemi obesitas, dan karena semakin banyak penelitian dalam pengelolaan berat badan berlanjut, faktor-faktor kontribusi baru terus ditemukan. Faktor-faktor tersebut adalah diet, ketidakatifan, gaya hidup dan perilaku makan, lingkungan, kondisi dan pengobatan kesehatan, faktor sosial budaya, psikologis, dan lainnya.

\subsection{Body Mass Index (BMI)}

Akumulasi lemak tubuh yang berlebihan yang mengganggu kesehatan menyebabkan obesitas dan masalah metabolisme [5]. Obesitas dan status berat diperkirakan berdasarkan indeks massa tubuh atau body mass index (BMI). Untuk menentukan BMI, massa tubuh dalam kilogram dibagi dengan tinggi dalam meter kuadrat. Jika upaya tidak dilakukan untuk menurunkan berat badan oleh orang gemuk, obesitas menjadi progresif dan kronis, dan ini memiliki konsekuensi buruk bagi kesehatan dan kualitas hidup [5], [6]. Perlu juga dicatat bahwa tidak semua obesitas merupakan hasil dari asupan kalori berlebih karena beberapa penyebab obesitas terkait non diet.

Lemak disimpan di berbagai wilayah tubuh, baik di tubuh bagian atas (area di sekitar perut dan perut) atau tubuh bagian bawah (area di sekitar pinggul, paha dan kaki) atau keduanya [7], [8]. Kelebihan lemak tubuh yang disimpan terutama dalam tubuh bagian atas menghasilkan obesitas tubuh bagian atas, juga dikenal sebagai obesitas bentuk apel atau obesitas perut [8]. Nama lain yang digunakan untuk menggambarkan obesitas tubuh bagian atas termasuk obesitas sentral, obesitas truncal atau obesitas android [3].

\subsection{Forward Chaining}

Solusi untuk beberapa masalah secara alami dimulai dengan pengumpulan informasi. Penalaran diterapkan pada informasi ini untuk mendapatkan kesimpulan logis. Sebagai contoh, seorang dokter biasanya mulai mendiagnosis seorang pasien dengan bertanya kepadanya tentang gejala-gejala yang dideritanya, seperti tekanan darah tinggi, suhu, sakit kepala, sakit tenggorokan, batuk, dll. Kemudian dokter menggunakan informasi ini untuk menarik kesimpulan yang masuk akal atau untuk membuat hipotesis untuk mengeksplorasi lebih lanjut. Cara berpikir seperti ini disebut dalam sistem data driven, forwardchaining [9].

Forward-chaining adalah model komputasi bottomup. Dimulai dengan serangkaian fakta yang diketahui dan menerapkan aturan untuk menghasilkan fakta baru yang propertinya cocok dengan fakta yang diketahui, dan melanjutkan proses ini hingga mencapai tujuan yang telah ditentukan, atau sampai tidak ada fakta lebih lanjut yang dapat diperoleh yang propertinya cocok dengan fakta yang diketahui. Ini memeriksa fakta terhadap permintaan atau tujuan yang telah ditentukan, dan menunjukkan bahwa kesimpulan bergerak maju dari fakta menuju tujuan [10].

\subsection{React Native}

React Native framework Javascript yang memungkinkan kita membuat aplikasi seluler hanya menggunakan JavaScript. Ini menggunakan desain yang 
sama seperti React, memungkinkan kita membuat UI seluler kaya dari komponen deklaratif. Dengan React Native, kita tidak membangun aplikasi web seluler, aplikasi HTML5, atau aplikasi hybrid; tetapi membuat aplikasi seluler nyata yang tidak dapat dibedakan dari aplikasi yang dibuat menggunakan Objective-C atau Java. React Native menggunakan blok bangunan UI dasar yang sama dengan aplikasi iOS dan Android biasa. Cukup menempatkan blok bangunan tersebut menggunakan JavaScript dan React [11].

\section{METODOLOGI}

Penelitian ini menggunakan metode Forward Chaining. Pada Metode Forward Chaining, penarikan kesimpulan (inference rules) dilakukan berdasarkan data yang sudah tersedia di dalam knowledge base. Dalam pengertian lain, forward chaining diartikan sebagai pendekatan yang dimotori data. Dalam pendekatan ini pelacakan dimulai dari informasi masukan, dan selanjutnya mencoba menggambarkan kesimpulan.

Karena sistem pakar ini ditujukan ke masyarakat yang ingin melakukan program diet dan untuk kalkulasi memerlukan usia 19 tahun, maka dapat disimpulkan syarat untuk pemakaian aplikasi ini adalah sebagai berikut :

1) Jangka usia 19 sampai 70 tahun

2) IMT / BMI inisial bernilai $18.5 \mathrm{ke}$ atas

3) Berat Badan Ideal lebih kecil dari Berat Badan Inisial

Berdasarkan syarat-syarat di atas maka aturan-aturan yang akan diimplementasikan dalam sistem pakar ini adalah

1) IF usia $<19$ OR usia $>70$ THEN usia tidak cukup

2) IF IMT $<18.5$ THEN diet tidak diperbolehkan

3) IF usia cukup THEN cek IMT

4) IF IMT $<18.5$ THEN IMT sehat

5) IF IMT sehat THEN kalkulasi berat badan ideal

6) IF berat badan inisial < berat badan ideal THEN user kurus

7) IF user tidak kurus THEN kalkulasi maksimal kalori per hari untuk program diet

Sebelum dan selama proses pengembangan aplikasi, penulis melakukan wawancara. Wawancara dilakukan dengan melakukan tanya jawab dengan pihak terkait (dalam hal ini dokter gizi) untuk mendapatkan informasi mengenai tubuh manusia dan makanan yang direkomendasikan untuk dikonsumsi selama pengguna aplikasi menjalankan proses diet.

Permasalahan pertama dalam penelitian ini adalah berat badan, untuk itu perlu diketahui berat badan inisial pengguna pada saat menggunakan aplikasi ini, dan juga berat badan ideal yang perlu dicapai berdasarkan rumus yang tersedia, dan pengguna perlu menginput berat badannya sesering mungkin untuk pembaruan perhitungan kalori yang diperlukan pengguna. Kemudian akan dikalkulasi dengan rumus yang telah dibedakan untuk jenis kelamin pengguna yang berbeda. Rumus yang akan digunakan merupakan data yang telah diperoleh dari hasil wawancara dengan dr. Lim Su Lin, yaitu:

a. Berat Badan Ideal $(\mathrm{kg})=$ Tinggi badan $(\mathrm{m} 2) \times 22$ $(\mathrm{kg} / \mathrm{m} 2)$

b. Batas Kalori untuk wanita $(\mathrm{kkal})=25 \mathrm{kkal} *$ Berat Badan Ideal (kg)

c. Batas Kalori untuk pria $(\mathrm{kkal})=30 \mathrm{kkal} *$ Berat Badan Ideal $(\mathrm{kg})$

\section{HASIL DAN ANALISIS}

\subsection{Entity Relationship Diagram (ERD)}

ERD menggambarkan desain database yang dirancang, yang mana dapat dilihat pada Gambar 1 bahwa perancangan database sistem ini hanya menggunakan 3 tabel dengan catatan user memiliki banyak data berat badan, dan tabel berat badan serta tabel user tidak memiliki hubungan dengan tabel makanan dikarenakan makanan yang di tampilkan akan dikalkulasi berdasarkan kalori user yang akan diproses di Backend.

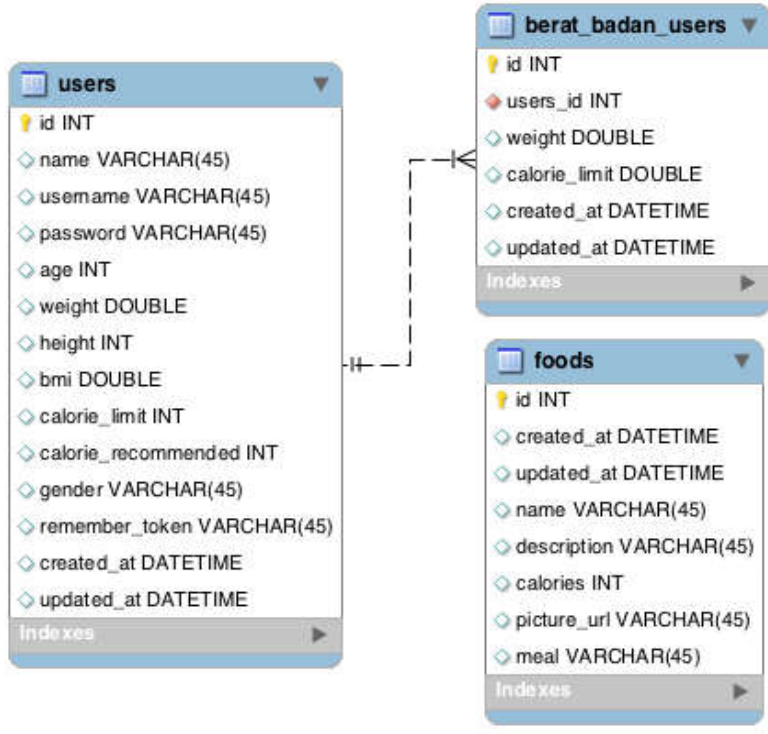

Gambar 1. Entity Relationship Diagram

\subsection{Desain Antarmuka Aplikasi}

Berikut adalah perancangan desain antarmuka aplikasi yang akan dibuat, segala desain adalah dalam bentuk portrait dikarenakan ini adalah desain antarmuka aplikasi mobile, yang pastinya desain ini akan memenuhi kebutuhan dan syarat-syarat yang perlu untuk memastikan informasi yang penting dapat disampaikan kepada pengguna aplikasi. 


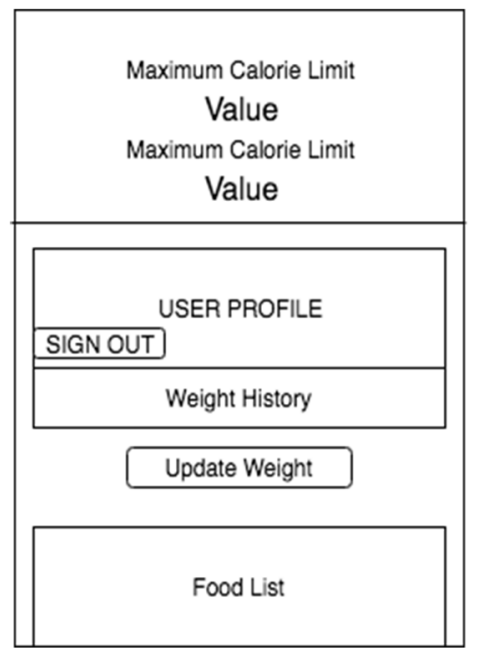

Gambar 2. Desain antarmuka aplikasi

\subsection{Perancangan Sistem}

Halaman pertama yang akan dilihat pengguna aplikasi pada saat instalasi pertama, pengguna aplikasi dapat melakukan otentikasi dengan memasukkan username dan password jika sudah punya akun sebelumnya, jika pengguna belum memiliki akun maka dapat menekan tombol Register di paling bawah tampilan halaman ini untuk mendaftar.

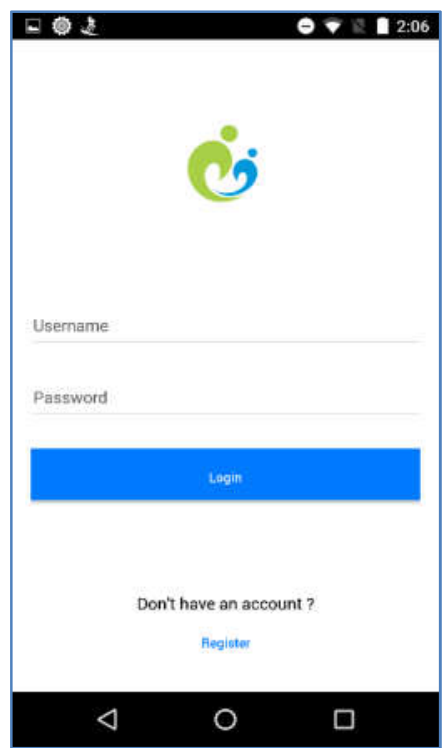

Gambar 3. Tampilan awal

Halaman Register pada Gambar 4 atau lebih dikenal dengan pendaftaran, dimana pengguna aplikasi dapat membuat akun baru dalam aplikasi ini untuk menjalankan program diet. Aturan-aturan sistem pakar yang menggunakan metode Forward Chaining dijalankan pada saat tombol Register ditekan, sistem akan validasi informasi yang dimasukkan oleh pengguna, jika informasi pengguna tidak sesuai maka akan muncul pesan pendaftaran gagal di halaman ini sesuai dengan alasan yang telah divalidasi oleh sistem.

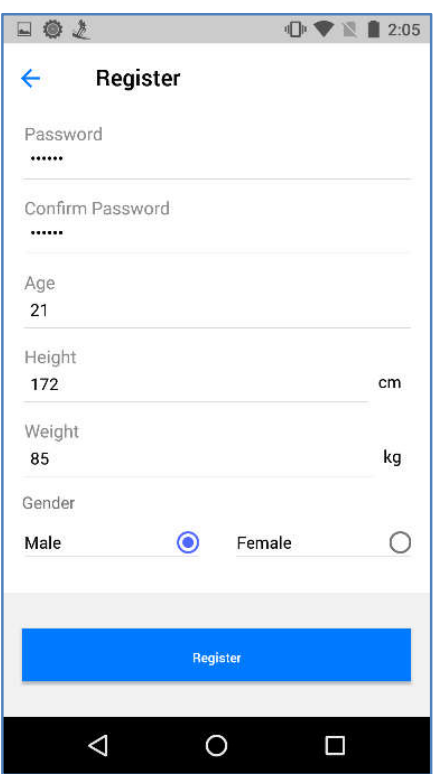

Gambar 4. Proses Registrasi akun

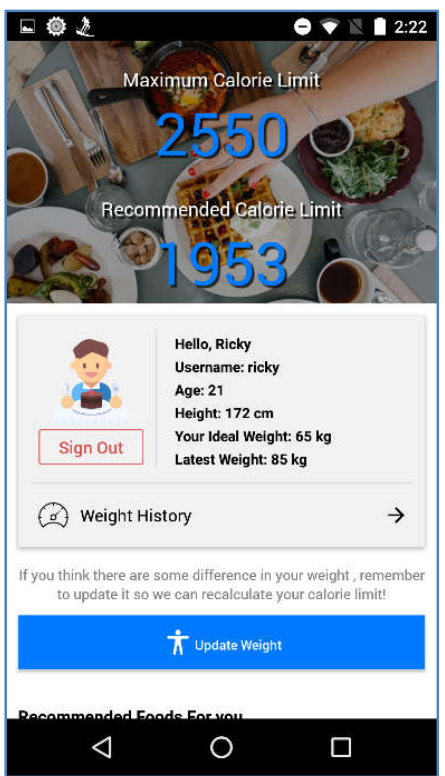

Gambar 5. Tampilan Halaman utama

Gambar 5 di atas ini merupakan halaman utama aplikasi, pada halaman ini pengguna aplikasi dapat langsung melihat informasi yang telah dimasukkan pada saat pendaftaran, dan juga nilai maksimal kalori dan rekomendasi maksimal kalori yang telah dikalkulasi oleh sistem berdasarkan informasi pengguna, yang dapat berubah sesuai dengan perubahan berat badan pengguna. Informasi ini dapat diperbaharui melalui tombol Update Weight yang berwarna biru, dan pengguna dapat melihat riwayat berat badannya dengan menekan tombol Weight History di sisi bawah informasi pengguna. 


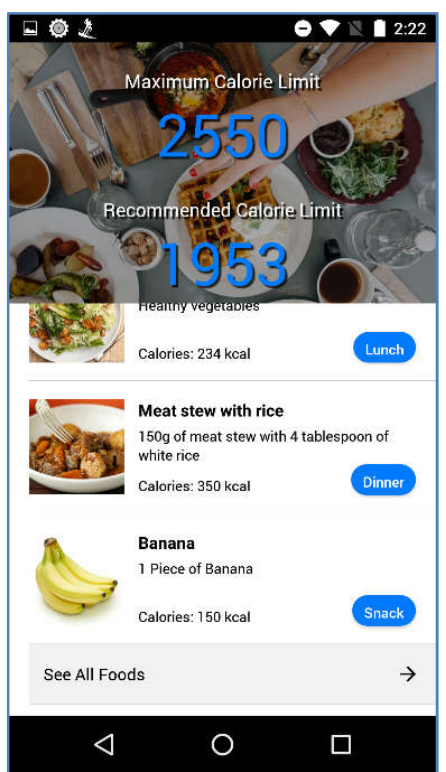

Gambar 6. Tampilan rekomendasi makanan

Gambar 6 dapat dilihat bagian bawah halaman utama terdapat rekomendasi makanan sesuai dengan kebutuhan kalori pengguna, pada paling dasar halaman terdapat tombol See All Foods adalah tombol yang akan navigasikan aplikasi ke halaman daftar makanan yang telah di rekomendasikan oleh pakar dan sumber tertentu, yang dapat dijadikan sebagai pedoman aturan makanan oleh pengguna. Pada langkah terakhir yang dapat dilakukan pengguna yaitu keluarkan akunnya dari aplikasi atau Sign Out di bawah gambar informasi pengguna.

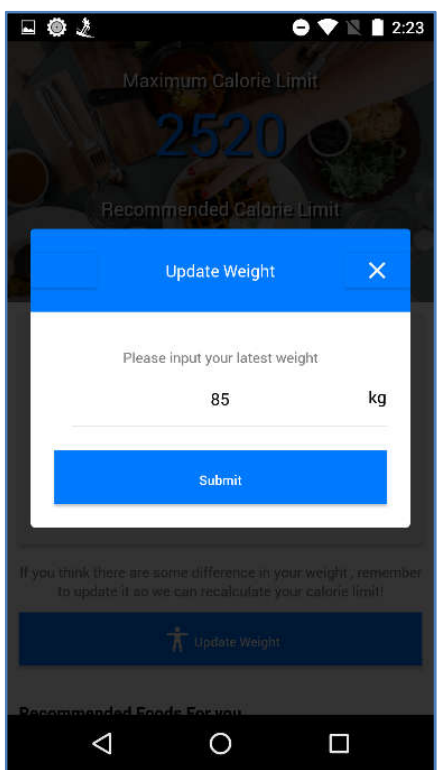

Gambar 7. Tampilan Update Weight

Gambar 7 merupakan tampilan Pop Up yang berisi satu kolom input dan juga satu tombol Submit yang telah disediakan kepada pengguna untuk memperbaharui data berat badannya jika pengguna telah mengalami perubahan berat badan, pada saat tombol biru tersebut ditekan maka sistem akan melakukan kalkulasi ulang jumlah kalori pengguna yang akan di perbaharui langsung di halaman utama aplikasi.

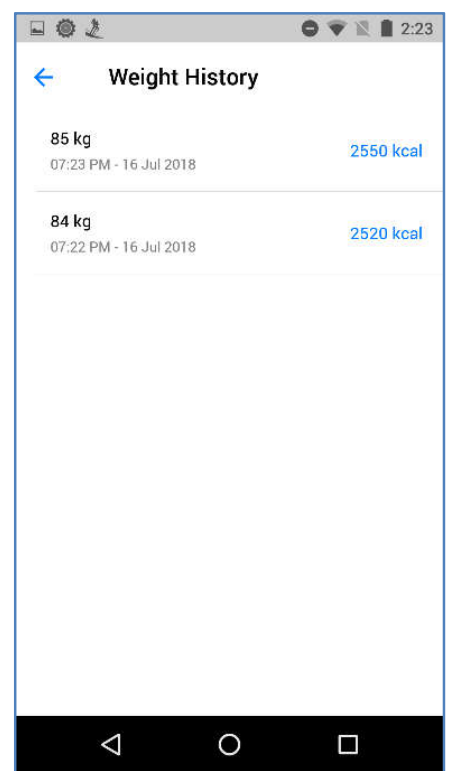

Gambar 8 Tampilan Weight History

Kemudian pada Gambar 8 pengguna dapat melihat riwayat perubahan berat badannya di halaman ini, pengguna dapat melacak informasi perubahan berat badannya yang tercantum waktu serta tanggal pembaharuan informasi, dan juga dapat melihat perbedaan maksimal kalori untuk masing masing berat badan.

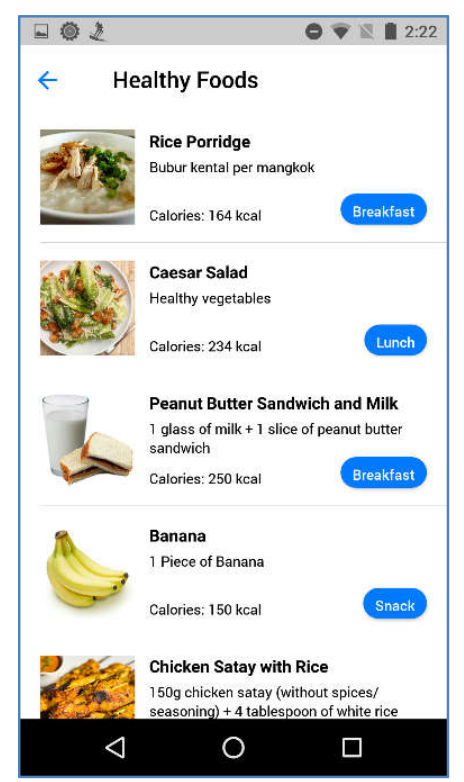

Gambar 9. Rekomendasi makanan

Tampilan Gambar 9 merupakan Halaman terakhir yang diperlihatkan, yang mana merupakan daftar makanan yang telah direkomendasikan oleh pakar untuk menyesuaikan maksimal kalori dan mencapai berat badan ideal. 


\subsection{Pengujian sistem}

Pengujian terhadap validasi sistem ini akan ditampilkan dalam bentuk Screenshot juga dari aplikasi dengan menampilkan informasi dan hasil yang diinput kedalam sistem, mengingat kembali aturan-aturan yang diimplementasi adalah sebagai berikut:

1) IF usia $<19$ OR usia $>70$ THEN usia tidak cukup

2) IF usia cukup THEN cek IMT

3) IF IMT $<18.5$ THEN diet tidak diperbolehkan

4) IF IMT $<30$ THEN IMT sehat

5) IF IMT sehat THEN kalkulasi berat badan ideal

6) IF berat badan inisial < berat badan ideal THEN user kurus

7) IF user tidak kurus THEN kalkulasi maksimal kalori per hari untuk program diet

Untuk pengujian, dapat dimasukkan skenario informasi yang salah agar dapat menguji hasil validasi dari sistem, dalam kasus ini diketahui bahwa informasi peneliti sendiri adalah sebagai berikut:

1) Nama Lengkap: Joyo Dikromo

2) Nama Pengguna: joyodikromo

3) Usia: 21 Tahun

4) Tinggi Badan: $176 \mathrm{~cm}$

5) Berat Badan: $56 \mathrm{~cm}$

6) Jenis Kelamin: Pria

Pada syarat pertama dicantumkan validasi usia terlebih dahulu, maka dalam tahap pengujian ini akan dimasukkan usia lebih kecil dari 19 tahun, yaitu 18 tahun, sedangkan jika dihitung dengan rumus kalkulasi BMI yang didapatkan oleh pakar, (berat badan / (tinggi badan m2)) BMI contoh termasuk tidak direkomendasikan untuk diet, maka seharusnya tidak melewati validasi yang ke-tiga, dan untuk kalkulasi berat badan ideal dari rumus yang telah diberikan pakar juga tidak melewati validasi selanjutnya dikarenakan berat badan ideal contoh sendiri lebih besar dari berat badan inisial, maka pendaftaran ini akan validasi yang dapat dilihat pada Gambar 10.

Sesuai dengan aturan yang telah ditetapkan, data pada contoh gagal dalam pendaftaran dikarenakan informasi yang dimasukkan kedalam sistem tidak sesuai dengan aturan yang telah ditetapkan, untuk validasi selanjutnya akan mengganti usia yang dimasukkan menjadi 21 yang akan lolos validasi, jika dilihat kembali informasi yang akan dimasukkan, seharusnya tidak lolos validasi ke 3, yaitu IMT dibawah 18.5.

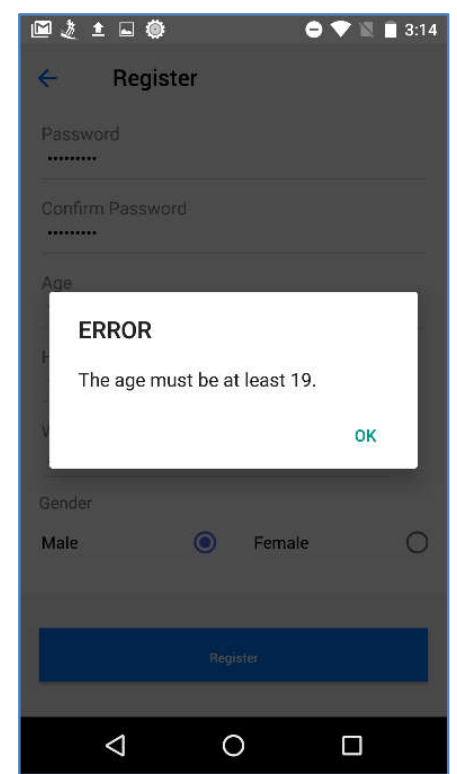

Gambar 10. Hasil validasi pertama

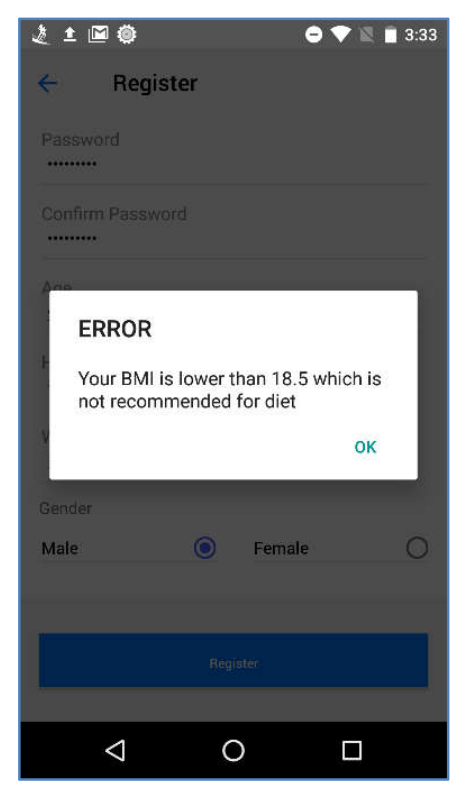

Gambar 11. Hasil validasi kedua

Pada validasi kedua ini sebagaimana ditunjukkan dalam Gambar 11 telah membuktikan validasi sistem masih berjalan dengan benar karena tidak memperbolehkan pengguna yang memiliki BMI di bawah normal untuk melaksanakan program diet. Untuk pengujian selanjutnya adalah pengujian berat badan ideal tidak boleh melebihi berat badan inisial dikarenakan pengguna akan tetap termasuk underweight walaupun BMI masih di dalam kondisi sehat. Maka berat badan yang diinput adalah 60 . 


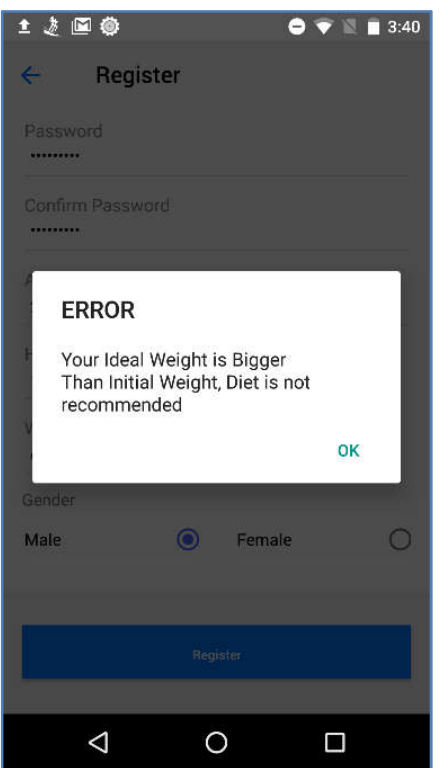

Gambar 12. Hasil validasi ketiga

Gambar 12 menunjukkan validasi ketiga berhasil menggagalkan pengguna untuk daftar dengan BMI sehat tetapi berat badan ideal masih lebih besar dari berat badan inisial. Untuk pengujian terakhir selanjutnya akan dimasukkan berat badan yang lebih dari normal, 100. Jika dibandingkan dengan validasi yang diberikan oleh pakar maka pengguna akan sukses daftar di dalam aplikasi dan mendapatkan nilai maksimal kalori yang disesuaikan dengan pola makan.

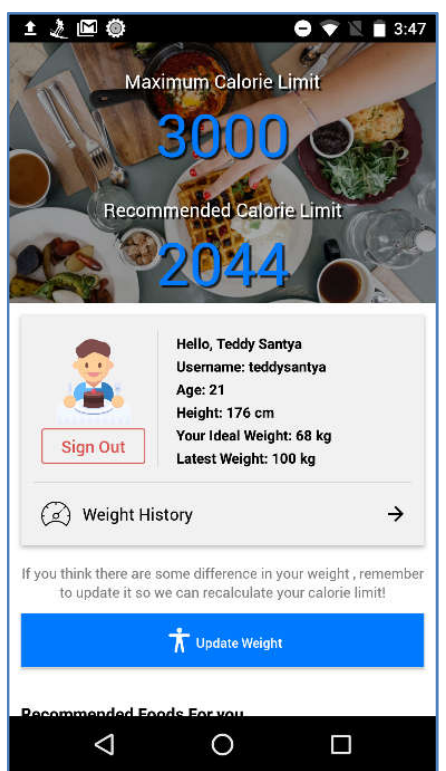

Gambar 13. Hasil perubahan informasi

Gambar 13 dapat dilihat informasi pengguna yang diganti untuk memenuhi syarat penggunaan aplikasi, dan mendapatkan nilai maksimal kalori sebanyak 3000 dan 2044 kalori perhari merupakan jumlah yang direkomendasi untuk mencapai berat badan ideal jika memiliki berat badan $100 \mathrm{~kg}$. Ini menunjukkan sistem telah berhasil menggunakan rumus yang diberikan oleh pakar. Maka sebagai contoh, seseorang dapat menyesuaikan pola makan dengan makanan-makanan yang direkomendasi oleh pakar, dan makanan yang muncul akan memiliki estimasi kalori lebih kecil dari maksimal kalori dibagi 3, untuk penyesuaian makan 3 kali sehari manusia.

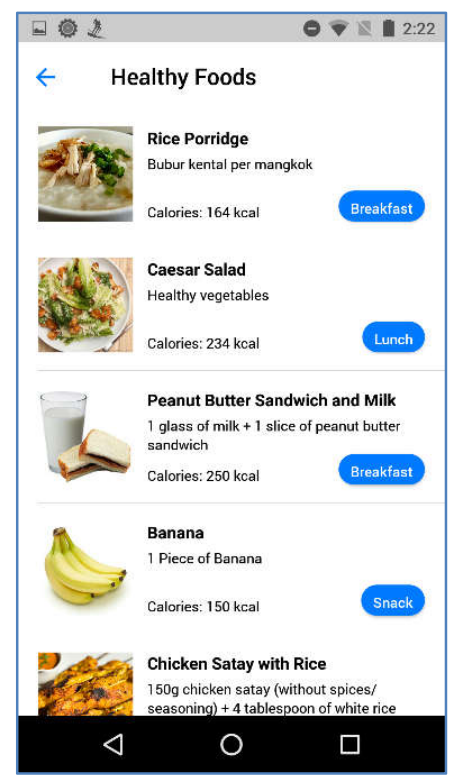

Gambar 14. Rekomendasi makanan

Gambar 14 adalah menu makanan yang dapat dijadikan referensi untuk mencapai berat badan ideal, ratarata memiliki kalori yang minimalis dan cukup sehat untuk menambah energi manusia, dapat direferensi makananmakanan yang direkomendasikan untuk makan pada waktunya , seperti potongan roti dan susu sebagai sarapan dan buah pisang sebagai cemilan.

\section{KESIMPULAN}

Berdasarkan hasil pengujian terhadap Aplikasi Sistem Pakar yang dibangun, kesimpulannya adalah program aplikasi sistem pakar dapat menyelesaikan masalah yaitu memberi cara menjalankan program diet yang benar dengan menyesuaikan pola makan dengan kalori yang dibutuhkan. Dan setiap ada perubahan pada berat badan pengguna maka nilai maksimal kalori juga akan berubah, karena maksimal kalori bergantung pada berat badan pengguna. Semua ini berjalan dengan benar dengan catatan informasi yang diinput ke dalam sistem merupakan data asli dari pengguna aplikasi, aplikasi ini juga mencegah terjadinya kesalahan pemakaian oleh pengguna yang sudah tidak direkomendasikan untuk diet dengan validasi pada tahap pendaftaran. Sehingga dari validasi itulah, pengguna aplikasi dapat menjalankan program diet dengan benar.

\section{DAFTAR PUSTAKA}

[1] K. K. R. Indonesia, "Hasil Utama Riskesdas 2018," Jakarta, 2018.

[2] R. J. Mahan KL, Escott-Stump S, "Nutrition in weight management," in Kraus's Food and 
Nutrition Care Process, Missouri: Elsevier Saunders, 2012.

[3] S. G. Uzogara, "Obvious and Hidden Calories in Food and their Impact on Weight, Obesity and Wellness: A Review," Adv. Obesity, Weight Manag. Control, vol. 4, no. 5, 2016.

[4] NHLBI, "Overweight and Obesity," National Heart, Lung, and Blood Institute, 2019. [Online]. Available: https://www.nhlbi.nih.gov/healthtopics/overweight-and-obesity. [Accessed: 10Sep-2019].

[5] G. SM, "Obesity, metabolic syndrome, and cardiovascular disease.," J Clin Endocrinol Metab, vol. 89, no. 6, p. 2595, 2004.

[6] H. C. Puhl RM, "Obesity stigma: important considerations for public health.," Am J Public Heal., vol. 100, no. 6, p. 1019, 2010.

[7] S. S. Karastergiou K, Fried SK, Xie H, Lee MJ, Divoux A, Rosencrantz MA, Chang RJ, "Distinct developmental signatures of human abdominal and gluteal subcutaneous adipose tissue depots.," $J$ Clin Endocrinol Metab, vol. 98, no. 1, p. 362, 2013.

[8] J. M. Santosa S, "Adipocyte fatty acid storage factors enhance subcutaneous fat storage in postmenopausal women.," Diabetes, vol. 62, no. 3, pp. 949-958, 2013.

[9] A. Al-Ajlan, "The Comparison between Forward and Backward Chaining," Int. J. Mach. Learn. Comput., vol. 5, no. 2, pp. 106-113, 2015.

[10] V. L. I Gaag, "Principles of Expert Systems," in Addison-Wesley, 1991, pp. 131-139.

[11] Tutorialpoint, "React Natice," 2017.

\section{BIODATA PENULIS}
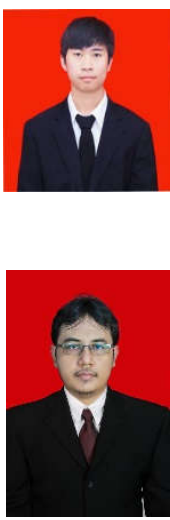

Teddy Santya

Alumni Program Studi Teknik Informatika Universitas Putera Batam. Programmer Mobile, bekerja pada perusahaan nasional ticketing.

\section{Cosmas Eko Suharyanto}

Alumni Magister Manajemen Sistem Informasi Universitas Bina Nusantara, Jakarta. Saat ini sebagai dosen tetap prodi Teknik Informatika Universitas Putera Batam.

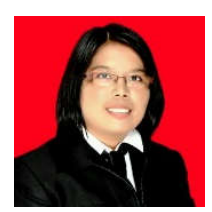

\section{Pastima Simanjuntak}

Alumni Magister Sistem Informasi STMIK Putera Batam. Saat ini sebagai dosen tetap prodi Teknik Informatika Universitas Putera Batam.

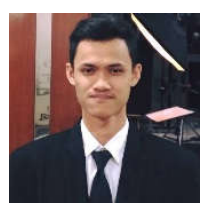

\section{Alex Alfandianto}

Alumni Teknik Industri, Universitas Teknologi Yogyakarta. IT Consultan Alfamedia Yogyakarta, juga bekerja pada perusahaan swasta multinasional. 